\title{
IKKepsilon involvement in Tax-mediated activation of INF pathway
}

\author{
Giorgia Cremonese*, Francesca Avesani, Erica Diani, Marco Turci, Gianfranco Di Gennaro, Umberto Bertazzoni, \\ Maria G Romanelli
}

From 15th International Conference on Human Retroviruses: HTLV and Related Viruses

Leuven and Gembloux, Belgium. 5-8 June 2011

HTLV-1 Tax de-regulates several cellular signaling pathways leading to cell transformation by altering gene expression, intracellular protein distribution and cell proliferation. Tax-1 induces persistent activation of several transcriptional factors and signal transduction pathways, including NF- $\kappa \mathrm{B}$ and CREB/ATF. It is known that Tax-1 constitutively activates TAK1 (transforming growth factor- $\beta$-activated kinase 1 ) and modifies the interferon (INF) regulatory signals by controlling the expression of INF transcription factors 3 (INF3) and INF4. We have recently reported that HTLV-1 and HTLV-2 Tax proteins interact with TAK1-binding protein 2 (TAB2) of the NF- $\kappa$ B pathway and that both Tax proteins transactivate NF- $\kappa \mathrm{B}$ promoters [1]. TAB2 functions as an adaptor protein to recruit TAK1 to TRAF2 (TNF- $\alpha$ receptor-associated factor) in TNF- $\alpha$ signaling pathways.

In the present study we have investigated Tax-1 and Tax -2 role in modifying INF and NF- $\kappa \mathrm{B}$ activation through the recruitment of IKKepsilon, an I $\kappa$ B kinase homologue involved in NF- $\kappa \mathrm{B}$ and INF3 signaling pathways. By co-immunoprecipitation experiments, we have found that both IKKepsilon and Tax-1, but not Tax-2, are present in protein complexes in transfected cells. IKKepsilon and Tax-1 or Tax-2 role in the activation of INF responsive elements or NF- $\kappa \mathrm{B}$ containing promoters have been analyzed after transfecting the protein genes in 293T cells and measuring the effect by luciferase assay. Co-expression of Tax-1 and IKKepsilon resulted in an increased IRF activation mediated by IKKepsilon. Interaction of IKKepsilon with Tax-1 and

* Correspondence: giorgia.cremonese@univr.it

Department of Life and Reproduction Sciences, Section of Biology and Genetics, University of Verona, Verona, Italy
Tax-2 and their possible effects in the de-regulation of the IRF3 pathways will be discussed.

\section{Published: 6 June 2011}

\section{Reference}

1. Avesani F, Romanelli MG, Turci M, Di Gennaro G, Sampaio C, Bidoia C, Bertazzoni U, Bex F: Association of HTLV Tax proteins with TAK1 binding protein 2 and RelA in calreticulin containing cytoplasmic structures participates in Tax-mediated NF KB activation. Virology 2010, 408:39-48.

doi:10.1186/1742-4690-8-S1-A137

Cite this article as: Cremonese et al:: IKKepsilon involvement in Taxmediated activation of INF pathway. Retrovirology 2011 8(Suppl 1):A137.

Submit your next manuscript to BioMed Central and take full advantage of:

- Convenient online submission

- Thorough peer review

- No space constraints or color figure charges

- Immediate publication on acceptance

- Inclusion in PubMed, CAS, Scopus and Google Scholar

- Research which is freely available for redistribution

Submit your manuscript at www.biomedcentral.com/submit
() Biomed Central
C Biomed Central

(c) 2011 Cremonese et al; licensee BioMed Central Ltd. This is an open access article distributed under the terms of the Creative Commons Attribution License (http://creativecommons.org/licenses/by/2.0), which permits unrestricted use, distribution, and reproduction in any medium, provided the original work is properly cited. 